\title{
PEMBERDAYAAN KELOMPOK KARANG TARUNA DALAM PROGRAM PEMBENIHAN IKAN LELE SECARA INTENSIF
}

\section{INTENSIVE CATFISH HATCHERYPROGRAM FOR THE EMPOWERMENT OF KARANG TARUNA GROUP}

\author{
${ }^{1)}$ Suwarsito, ${ }^{2)}$ Hindayati Mustafidah \\ ${ }^{1)}$ Program Studi Pendidikan Geografi, FKIP, Universitas Muhammadiyah Purwokerto, ${ }^{2}$. Program Studi \\ Teknik Informatika, Fakultas Teknik, Universitas Muhammadiyah Purwokerto \\ J1. Raya Dukuh Waluh PO BOX 202 Purwokerto 53182 \\ Telpon: (0281)636751 ext : 130 Fax (0281)637239 \\ Email: ito_warsito@yahoo.co.id
}

\begin{abstract}
ABSTRAK
Program pengabdian masyarakat ini bertujuan untuk meningkatkan pengetahuan dan ketrampilan kelompok Karang Taruna di Desa Gandatapa, Kecamatan Sumbang, Kabupaten Banyumas dalam kegiatan pembenihanikan lele dumbo secara intensif. Metode pengabdian masyarakat yang digunakan adalah pelatihan dan praktek langsung. Kegiatan pelatihan meliputi pemijahan induk ikan lele dumbo menggunakan teknologi kawin suntik (induce breeding), pelatihan pemeliharaan larva ikan menggunakan sistem inkubator, dan pelatihan kewirausahaan. Sedangkan metode pendekatan pelaksanaan pengabdian masyarakat melalui tatap muka, pembimbingan, pendampingan, dan kemitraan dengan kelompok Karang Taruna. Hasil kegiatan pengabdian masyarakat ini telah dapat meningkatkan pengetahuan dan keterampilan kelompok Karang Taruna di Desa Gandatapa dalam melakukan pembenihan ikan lele secara intensif mulai dari proses pemijahan induk ikan lele menggunakan teknologi kawin suntik, pemeliharaan larva ikan menggunakan sistem inkubator, manajemen pemberian pakan dan kualitas air, serta manajemen usaha. Luaran program pengabdian masyarakat yang dihasilkan adalah benih ikan lele ukuran $3-4 \mathrm{~cm}$.
\end{abstract}

Kata kunci:Karang Taruna, pemijahan ikan, Ikan Lele Dumbo, induce breedin

\section{ABSTRACT}

This community service program aims to improve the knowledge and skills of youth organization (Karang Taruna) group in Gandatapa Village, Sumbang Subdistrict, Banyumas Regency in intensive catfish hatchery. Community service program used training and direct practice method. Training activities include broodstock catfish spawning using induce breeding technology, fish larvae maintenance using incubator system, and entrepreneurship. Approach method of community service were direct interaction, mentoring, and partnership with Karang Taruna group. The results of this community service activity have been increase the knowledge and skill of Karang Taruna group at intensive catfish hatchery, consists of spawning broodstock catfish process using induce breeding technology, fish larva maintenance using incubator system, feeding management and water quality, as well as business management. Output of community service program have resulted 3 - $4 \mathrm{~cm}$ catfish fingerling.

Keywords: Karang Taruna group, Catfish hatchery, induce breeding

Submited : 30 Maret 2017 Revision : 14 Juni $2017 \quad$ Accepted : 7 September 2017

\section{PENDAHULUAN}

Desa Gandatapa mempunyai potensi yang baik untuk pertanian dan budidaya perikanan. Desa ini mempunyai sumber air yang melimpah yang berasal dari mata air pegunungan Slamet. Kondisi air di desa tersebut melimpah sepanjang tahun dan bebas dari pencemaran sehingga sangat mendukung untuk usaha budidaya 
perikanan.Kondisi curah hujan yang tinggi juga sangat mendukung ketersediaan air di Desa Gandatapa. Selain itu, kondisi jalan juga cukup baik dan mudah untuk dijangkau oleh moda transportasi.Namun potensi alam yang melimpah tersebut belum memberikan manfaat yang banyak bagi masyarakat desa tersebut karena belum dikelola secara optimal. Hal ini disebabkan karena masih rendahnya tingkat pengetahuan masyarakat dalam pengelolaan sumberdaya alam.

Di Desa Gandatapa terdapat organisasi Karang Taruna yang anggotanya terdiri dari para pemuda yang kebanyakan putus sekolah dan tidak mempunyai pekerjaan tetap. Jumlah anggota karang taruna sebanyak 30 orang. Organisasi Karang Taruna di Desa Gandatapa ini sudah mulai merintis berbagai usaha, seperti usaha pembenihan ikan lele dumbo di kolam terpal, usaha konveksi, dan usaha pembuatan kerajinan dari kain flanel. Salah satu usaha karang taruna yang sekarang digeluti adalah kelompok usaha pembenihan ikan lele dumbo. Saat ini, anggota karang taruna yang aktif menggeluti usaha pembenihan ikan lele sebanyak 8 orang. Masing-masing anggota kelompok hanya mempunyai 1-2 kolam terpal ukuran $2 \times 3 \mathrm{~m}^{2}$. Produksi benih setiap kolamnya hanya sekitar 2000 ekor. Usaha pembenihan ikan lele dumbo juga masih dilakukan secara sederhana dan tradisional sehingga keuntungannya belum maksimal.

Berdasarkan hasil wawancara dengan ketua Karang Taruna di Desa Gandatapa, dijumpai adanya beberapa permasalahan dalam usaha pembenihan ikan lele dumbo, yaitu : 1) Jumlah kolam pembenihan ikan masih terbatas (setiap anggota hanya mempunyai $1-2$ kolam terpal ukuran 2 x 3 $\mathrm{m}^{2}$ ) sehingga produksi benih ikan masih rendah (1000 ekor benih tiap kolam), 2) Belum mempunyai induk ikan sendiri sehingga masih membeli larva ikan lele ukuran 3-4 cm dari pembenih ikan di luar desanya lalu dipelihara selama 1 bulan hingga ukuran $7-9 \mathrm{~cm}$, selanjutnya dijual.
3) Belum mempunyai pengetahuan dan keterampilan yang memadai dalam memijahkan induk ikan lele dumbo secara intensif dengan system incubator sehingga hidup benih ikan lele masih rendah. 3) Kemampuan manajemen usaha masih rendah dan pemasaran produksi benih ikan masih lokal.

Berdasarkan permasalahan di atas, program pengabdian masyarakat ini bertujuan untuk meningkatkan pengetahuan dan ketrampilan kelompok Karang Taruna dalam kegiatan pembenihanikan lele dumbo secara intensif.

\section{METODE}

Program pengabdian masyarakatinimenggunakanmetodepelatiha $\mathrm{n}$ dan praktek langsung. Berdasarkan kesepakatan antarapengusul bersama mitra, kegiatan pelatihan yang dilaksanakan adalah pemijahan induk ikan lele dumbo menggunakan teknologi kawin suntik (induce breeding) (Assubuki,2002; Sugumar, and Munuswamy, 2006), pelatihan pemeliharaan benih ikan menggunakan sistem inkubator, dan pelatihan kewirausahan. Frekuensi masingmasing kegiatan pelatihan dilakukan selama 3 kali, yaitu diawali dengan penyampaian materi, dilanjutkan dengan praktek langsung, dan pendampingan selama kegiatan berlangsung. Peserta pelatihan adalah 10 orang berasal dari Karang Taruna Desa Gandatapa.

Metode pendekatan pelaksanaan program pengabdian masyarakat melalui tatap muka, sosialisasi program, pendampingan,pembimbingan, dan kemitraan dengan kelompok Karang Taruna. Sosialisasi program dilakukan dengan tatap muka untuk menyampaikan program kegiatan pengabdian masyarakat kepada kelompok sasaran. Kegiatan pelatihan dilakukan dengan sistem perkuliahan dilanjutkan dengan praktik dan pembuatan demplot (kolam percontohan). Penyampaian materi menggunakan metode 
ceramah, diskusi, dan simulasi. Praktik pemijahan ikan lele dilakukan secara langsung mulai prosespemilihan induk ikan lele, persiapan bahan dan peralatan serta tempat dan media pemijahan ikan, proses penyuntikan induk ikan lele dengan hormon ovaprim, penetasan telur, perawatan larva, manajemen pemberian pakan, dan pengelolaan kualitas air. Selain itu, untuk meningkatkan kemampuan manajemen usaha dilakukan pelatihan kewirausahaan yang meliputi analisa usaha, pembukuan keuangan sederhana, dan pemasaran usaha.

Pendampingan dilakukan mulai dari
kegiatan pembuatan demplot kolampemijahan ikan lele, pemeliharaan larva, dan pemeliharaan benihikan lele. Pembimbingan dilakukan dengan membimbing dan memantau secara langsung kegiatan pembenihan ikan lele secara rutinselama dua siklus produksi. Kemitraan dilakukan dengan memberikan bantuan modal untuk sarana dan prasarana pembenihan ikan lele serta bantuan teknis.

Dalam kegiatan ini, kelompok Karang Taruna sebagai mitra kegiatan ini berpartisipasi aktif selama pelatihan, persiapan sampai pelaksanaan dan pemantauan kegiatan pembenihan ikan lele. Bentuk partisipasi lain adalah mempersiapkan peralatan, tempat, dan tenaga untuk pelaksanaan kegiatan pembenihan ikan lele. Setelah selesai kegiatan, kelompok Karang Taruna juga berkewajiban merawat sarana dan prasarana yang telah diberikan serta mengembangkan usaha pembenihan ikan tersebut agar memberikan manfaat terhadap peningkatan pendapatan kelompok pembudidaya ikan dan masyarakat sekitarnya.

\section{HASIL DAN PEMBAHASAN}

Hasil pelaksanaan program
pengabdianmasyarakattelah berhasil
mencapai target dan luaran yang telah
ditetapkan. Hasil kegiatan pelatihan
pemijahan induk ikan lele dumbo adalah

telah berhasil meningkatkan pengetahuan dan keterampilan kelompok Karang Taruna dalam memijahkan induk ikan lele dumbo menggunakan teknologi induce breeding. Anggota kelompok Karang Taruna telah mampu mempraktekkan cara pemilihan induk ikan lele yang baik yang siap dipijahkan. Anggota kelompok tersebut mampu membedakan induk jantan dan betina. Ciri-ciri induk jantan yang siap memijah adalahwarna tubuh agak kemerahmerahan, alat kelamin tampak jelas meruncing, tubuh tetap ramping dan gerakannya lebih lincah, serta bila diurut ke arah anus keluar cairan sperma berwarna putih. Sedangkan ciri-ciri induk betina yang siap memijah adalah perut tampak besar dan bila diraba terasa lembek, alat kelamin berwarna kemerahan dan lubangnya agak membesar, serta bila diurut ke arah anus keluar telur berwarna kekuningan. Induk ikan lele yang digunakan untuk praktek pemijahan adalah ikan lele dumbo lokal dan lele dumbo Sangkuriang.

Anggota kelompok Karang Taruna juga sudah mampu menyiapkan media yang digunakan untuk pemijahan ikan. Media pemijahan tersebut adalah kolam dari terpal plastik yang berisi air bersih dan bening yang sudah didiamkan selama sekitar 3 hari dengan ketinggian air sekitar $20 \mathrm{~cm}$. Pada media air diberi desinfektan methylene blue untuk mencegah tumbuhnya jamur. Pada media tersebut juga ditaruh paranet yang ditenggelamkan di dasar kolam pemijahan. Paranet tersebut berfungsi sebagai tempat penempelan telur ikan lele ketika ikan lele telah memijah.

Dari kegiatan praktik langsung penyuntikan induk ikan lele, anggota kelompok Karang Taruna sudah mampu melakukan proses penyuntikan induk ikan mulai dari penyiapan hormon, penentuan dosis, dan cara penyuntikan. Hormon yang digunakan untuk penyuntikan ikan lele adalah ovaprim.Ovaprim merupakan hormon analog GnRH (Gonadotropin Releasing Hormone) sintetis yang 
mengandung domperidome (Sugumar and Munuswamy, 2006). GnRH dalam ovaprim berfungsi memperlancar pelepasan gonadotropin dari kelenjar pituitary yang selanjutnya akan menginduksi proses pematangan akhir sel-sel kelamin (gamet) (Tang dan Affandi, 2000). Penggunaan ovaprim ini dapat merangsang pematangan gonad dan mengatur waktu pemijahan ikan. Assubuki (2002)menyarankan bahwa penggunaan hormon ovaprim yang optimum untuk pemijahan ikan lele dumbo adalah $0,3 \mathrm{ml} / \mathrm{kg} / \mathrm{berat}$ badan ikan. Hormon ovaprim dapat diperoleh di pasaran bebas di toko penjual bahan dan peralatan budidaya perikanan.

Dosis ovaprim yang digunakan adalah $0,2 \mathrm{ml} / \mathrm{kg}$ induk jantan dan $0,7 \mathrm{ml} / \mathrm{kg}$ induk betina. Penyuntikan dilakukan pada bagian punggung dengan memasukkan jarum suntik dengan posisi miring $45^{\circ}$ sedalam $\pm 2 \mathrm{~cm}$. Induk yang telah disuntik, dilepas ke dalam kolam pemijahan yang telah dipersiapkan. Kemudian kolam pemijahan ditutup dengan jaringagar ikan tidak meloncat pada saat proses pemijahan. Proses penyuntikan induk ikan lele dilakukan pada sore hari sekitar pukul 17.00. Penyuntikan dengan hormon ovaprim dimaksudkan untuk menginduksiatau menimbulkan rangsangan bagi ikan untuk memijah (Susanto, 2002). Perangsangan pematangan gonad dengan terapi hormonal adalah untuk merangsang lebih aktifnya kelenjar hipofisa dalam menghasilkan hormon gonadotropin $(\mathrm{GtH})$ yang dapat mempengaruhi tingkat kematangan gonad secara terkontrol.Mekanisme kerja hormon gonadotropin dalam mempercepat pematangan gonad menurut Nagahama et al., (1995) adalah pituitaryakan mensekresikan GtH I dan GtH II. GtH I akan bekerja pada sel-sel theca yang menghasilkan testosteron. Testosteron akan merangsang sintesis vitellogenin yang selanjutnya dilepaskan ke aliran darah dan diserap oleh sel telur sehingga sel telur berkembang menjadi besar sampai fase dorman menunggu sinyal lingkungan lain yang dapat merangsang pelepasan GtH II. Hormon utama yang merangsang pelepasan telur pada ikan adalah GtH II.

Pemijahan ikan terjadi pada dini hari, yaitu sekitar 16 jam setelah penyuntikan. Hasil praktik pemijahan induk ikan yang pertama belum berhasil. Induk ikan lele betina yang dipijahkan memang berhasil bertelur dan telurnya ditempelkan di media paranet yang ada di kolam pemijahan.Jumlah telur yang dihasilkan dari pemijahan tersebut juga banyak, namun tidak menetas. Pada awalnya, telur-telur ikan tersebut berwarna kuning, namun setelah satu hari berubah warna menjadi putih keruh, bahkan dua hari berikutnya telah ditumbuhi jamur. Hal ini terjadi, diduga telur-telur ikan tidak dibuahi oleh sperma induk jantan. Diduga induk jantan gonadnya belum matang sempurna sehingga kualitas spermanya juga kurang baik dan tidak dapat membuahi telur-telur yang telah dikeluarkan oleh induk betina. Oleh karena itu, kolam pemijahan ikan dikuras dan dibersihkan lagi untuk digunakan pada praktik pemijahan berikutnya. Kegagalan praktik pemijahan induk ikan yang pertama ini telah memberikan pelajaran dan pengalaman yang berharga bagi kelompok Karang Taruna tersebut. Dari kegagalan tersebut, selanjutnya dilakukan evaluasi dan tindakan perbaikan agar pada praktek berikutnya berhasil.

Hasil praktik pemijahan induk ikan berikutnya telah berhasil memijahkan induk ikan lele.Pada praktik pemijahan yang kedua ini ini menggunakan dua pasang induk lele Sangkuriang.Induk ikan berhasil memijah dan induk-induk betinanya menghasilkan telur berkisar antara 20.000 sampai 40.000 butir. Telur yang dihasilkansebagian besar berwarna kuning bening. Hal ini menunjukkan bahwa telur telah dibuahi dengan sempurna oleh sperma induk jantan. Telur yang berwarna bening ini akan menetas menjadi larva ikan.Hari 
ketiga setelah penetasan, telur-telur tersebut sudah menetas menjadi larva.

Pada hari ke-4,larva ikansudah mulai makanpakanalami cacing sutera yang diberikan dengan cara ed libitum. Cacing sutera ini merupakan pakan alami yang paling cocok untuk pakan larva ikan karena mengandung nutrisi yang tinggi dan lengkap. Cacing sutera mempunyai kelebihan sebagai pakan alami, yaitu kandungan proteinnya tinggi $(57 \%)$ dan kandungan lemaknya 13,3\% (Zonneveld et al., 1991), mudah dicerna oleh benih ikan karena mengandung enzim proteolisis yang membantu proses pencernaan benih ikan, disukai oleh benih ikan, tidak mencemari air, dan mudah dibudidayakan secara masal dalam waktu singkat (Khairuman et al., 2008). Dari hasil penelitian Pursetyo (2008), cacing ini mempunyai peranan penting karena mampu memacu pertumbuhan ikan lebih cepat dibandingkan pakan alami lain seperti Daphnia sp. atau Moina sp. Sedangkan menurut hasil penelitian Chumaedi dan Priyadi (2006) menunjukkan bahwa pemberian pakan hidup cacing sutera (Tubifex sp.) dapat meningkatkan laju pertumbuhan harian benih botia (Chromobotia macracanthus Bleeker) paling tinggi dibanding pemberian kutu air (Moinasp.) dan nauplii Artemia sp. Pemberian pakan alami cacing sutera dapat mempercepat pertumbuhan dan meningkatkan kelangsungan hidup larva ikan.

Setelah berumur tiga minggu, larva ikan mulai makan pakan buatan yang berbentuk tepung yang diberikan dengan dosis $15 \%$ dari bobot larva ikan lele. Kandungan protein pakan untuk larva ikan tersebut lebih dari $35 \%$. Kandungan protein yang tinggi dapat mempercepat proses pertumbuhan larva ikan. Menurut Riva'i (2011), kebutuhan protein ikan tergantung pada jenis dan tingkatan stadianya. Ikan pada stadia dini memerlukan jumlah protein yang tinggi karena untuk mempertahankan hidup dan untuk pertumbuhan.
Selama pemeliharaan larva ikan, kondisi air dipertahankan agar tetap bersih dan jernih. Kualitas air yang cocok untuk pertumbuhan dan kelangsungan hidup larva ikan lele menurut Medinawati et al (2011) adalah temperatur air berkisar antara 26 $31^{\circ} \mathrm{C}, \quad \mathrm{pH}$ berkisar antara $7-8$, dankandungan oksigen terlarut 4,4 - 4,6 ppm.

Setelah berumur satu bulan, benih ikan mencapai ukuran $3-4 \mathrm{~cm}$ dan mulai didederkan di kolam lain yang lebih luas. Selanjutnya, benih ikan disortir untuk mendapatkan ukuran yang seragam. Benih ikan yang berukuran lebih besar atau lebih kecil dipisahkan dan dipelihara pada kolam tersendiri. Dari hasil kegiatan pemeliharaan larva hingga menjadi benih ikan ini, tingkat kelangsungan hidupnya relatif tinggi (sekitar 90\%). Hal ini didukung kondisi kualitas air yang stabil karena dipelihara dalam kolam menggunakan sistem inkubator. Dengan sistem inkubator memungkinkan temperatur air media pemeliharaan larva relatif stabil dan hangat dan terlindung dari curahan air hujan secara langsung. Dengan kondisi media pemeliharaan larva ikan yang stabil akan meningkatkan nafsu makan larva, terlihat dari pakan yang diberikan habis dikonsumsi semua oleh larva ikan. Daya tahan dan pertumbuhan ikan meningkat sehingga kelulushidupan larva juga tinggi.

Kegiatan pelatihan kewirausahaan telah dapat meningkatkan pengetahuan dan keterampilan kelompok pembudidaya ikan dalam melakukan manajemen usaha. Pelatihan manajemen usaha diperlukan agar usaha pembenihan ikan lele tersebut berjalan dengan baik dan profesional, terutama ditinjau dari aspek keuangannya. Analisis usaha diperlukan untuk menilai kelayakan usaha pembenihan ikan lele yang sedang dijalankan. Sedangkan pemasaran usaha diperlukan untuk memasarkan produk benih ikan lelenya. Pelatihan manajemen usaha yang telah meliputi cara menganalisis usaha, pembukuan sederhana, 
dan pemasaran usaha. Pelatihan pemasaran usaha meliputi cara menjalin kerjasama dengan mitradan pengembangan pemasaranmenggunakan web site.Kelompok Karang Taruna dilatih untuk menjalin kerjasama dengan para pembudidaya ikan untuk memasarkan hasil benih ikan lele. Selain itu, Kelompok Karang Taruna juga dilatih menjalin kerjasama dengan instansi terkait seperti Dinas Perikanan dan Peternakan Kabupaten Banyumas untuk membantu pemasaran dan penambahan modal usaha.

\section{SIMPULAN}

Hasil kegiatan pengabdian masyarakat ini telah dapat meningkatkan pengetahuan dan keterampilan kelompok Karang Taruna di Desa Gandatapa dalam melakukan pembenihan ikan lele secara intensif mulai dari proses pemijahan induk ikan lele menggunakan teknologi kawin suntik, pemeliharaan larva ikan menggunakan sistem inkubator, manajemen pemberian pakan dan kualitas air, serta manajemen usaha. Luaran programpengabdian masyarakat yang dihasilkan adalah benih ikan lele ukuran 3 $4 \mathrm{~cm}$.

Berdasarkan hasil kegiatan pengabdian masyarakat yang dilaksanakan, disarankan untuk menjalin mitra kerjasama dengan pembudidaya ikan dan Dinas Perikanan setempat untuk mengembangkan pemasaran dan modal usaha.

\section{UCAPAN TERIMA KASIH}

Ucapan terima kasih kami sampaikan kepada Direktorat Riset dan Pengabdian Masyarakat (DRPM) Kemenristek-Dikti yang telah memberikan dana untuk pelaksanaan program pengabdian masyarakat ini.

\section{DAFTAR PUSTAKA}

Assubuki, I. (2002). Pengaruh penggunaan hormon ovaprim dengan dosis yang berdeda terhadap waktu latensi pemijahan ikan lele dumbo (Clariasgariepinus). Tesis. Jurusan Ilmu Peternakan, Universitas Muhammadiyah Malang.

Chumaedi \& Priyadi. (2006). Pendederan benih botia (Chromobotia macracanthus Bleeker) dengan pemberian berbagai pakan hidup. Prosiding Seminar Nasional Perikanan. Fakultas Pertanian. Universitas Gadjah Mada, Yogyakarta.

Khairuman, K. Amri, dan T. Sihombing. (2008). Budidaya cacing sutera. Jakarta : Agromedia Pustaka.

Medinawati, Novalina S., Yoel. (2011). Pemberian Pakan Yang BerbedaTerhadap Pertumbuhan danKelangsungan Hidup Benih LeleDumbo (Clarias gariepinus). Media Litbang Sulteng IV(2) : 8387.

Nagahama, Y., M. Yoshikuni, M. Yamashita, T. Tokumoto, and Y. Katsu. (1995). Regulation of oocyte growth and maturation in fish. P.: 103 - 145. In: Pedersen, R.A. and G.P. Chatten (eds.). Current topics in developmental biology. Vol. 30. New York: Academic Press

Riva'i, A. (2011).Aspek Nutrisi Pakan Ikan. Aquaculture Newsletter, edisi 4 Juli 2011.

Sugumar, V. and N. Munuswamy. (2006). Effect of single intramuscular injection of Ovaprim-C on induced spawning and fecundity of sustainable fish Grass carp Ctenopharyngodon idella at Fish Hatchery Islamabad, Pakistan. Journal of Aquaculture 258 (1) : $529-534$

Suwarsito dan A. Suyadi. (2010). Upaya Meningkatkan Produksi Benih Ikan Lele Dumbo (Clarias gariepinus) 
Menggunakan Teknologi

Pemijahan Kawin Suntik. Laporan

Kemitraan. LPPM Univ. Muh.

Purwokerto (tidak dipublikasikan).

Tang, U. Dan R. Affandi. (2002). Fisiologi

Hewan Air. Riau : Universitas Riau Press

Zonneveld, N., E.A. Huisman, and J.H.

Boon. (1991). Prinsip-prinsip

budidaya ikan. Jakarta : Gramedia

Pustaka Utama 